\title{
DIRASAH
}

Volume 3, Number 2, Agustus 2020

p-ISSN: 2615-0212 | e-ISSN: 2621-2838

https://ejournal.iaifa.ac.id/index.php/dirasah

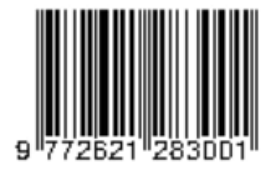

\begin{tabular}{|c|c|c|}
\hline Accepted: & Revised: & Published: \\
Mei 2020 & Juni 2020 & Agustus 2020 \\
\hline
\end{tabular}

\section{Integrasi Nilai Agama pada Pembelajaran IPS dalam Membina Self Control Siswa}

\author{
Mukti Ali ${ }^{1}$, Siti Rohmah ${ }^{2}$ dan Nur Hidayati Andrajati ${ }^{3}$ \\ IAIN Salatiga, Salatiga, Indonesia \\ e-mail:1ali.nisrina@gmail.com, ${ }_{3}$ sitirohmah92378@gmail.com, \\ nabhanraif@gmail.com
}

\begin{abstract}
(This study aims to describe the conception of religious values by learning social science in students' Self control through integrative patterns and goals. Humans are actually social creatures, so we need some self-mastery when it blends into the environment. Controlling yourself or controlling yourself is an effort that is done with what is being done. Having a good self-control ability means being able to communicate positively, and vice versa. The pattern of integration created by incorporating religious values into social studies learning can be an alternative to the whole. The research method used is descriptive research methods and interpretation. The conclusion from the results of this study is that religion and social studies learning support that can be a reference in self-development. The results obtained can be learning in fostering self-supervision.
\end{abstract}

Keywords: Self control, integration patterns, IPS, Religion. 


\section{Abstraksi}

Penelitian ini bertujuan untuk mendeskripsikan konsepsi nilai agama dengan pembelajaran IPS dalam membina Self control peserta didik melalui pola dan pendekatan integratif. Manusia sejatinya merupakan mahluk sosial, maka diperlukan suatu pengendalian diri saat membaur ke dalam lingkungannya. Mengendalikan diri atau Self control merupakan upaya sadar dengan apa yang sedang dilakukan. Memiliki kemampuan Self control yang baik artinya mampu mengarahkan ke perilaku positif, begitupun sebaliknya. Pola integrasi yang dibentuk dengan memasukkan nilai agama kedalam pembelajaran IPS dapat menjadi alternatif secara keseluruhan. Metode penelitian yang digunakan penulis adalah metode penelitian deskriptif dan interpretasi. Kesimpulan dari hasil penelitian ini adalah agama dan pembelajaran IPS memiliki kesamaan yaitu dapat menjadi acuan dalam pengembangan diri. Hasil yang diperoleh keduanya dapat menjadi pembelajaran dalam membina pengendalian diri.

Kata kunci: Self control, pola integrasi, IPS, Agama.

\section{Pendahuluan}

Melalui pendidikan manusia bisa mengembangkan kehidupannya ke taraf yang lebih baik, itulah mengapa pendidikan sangat penting dalam kehidupan manusia. Pendidikan merupakan perantara mengenalkan dan memberikan pengetahuan serta nilai-nilai yang bisa diterapkan dalam kehidupan. Persoalan pendidikan selain dipahami sebagai proses, juga sebagai hasil. Menurut Ahmadi, hasil pendidikan bisa berupa hubungan interaksi manusia dengan linkungannya. ${ }^{1}$

Ilmu pengetahuan sosial merupakan bidang ilmu yang mengkaji tentang kehidupan manusia dalam kelompok baik dalam kelompok kecil ataupun dalam kelompok besar. Dengan kata lain bagaimana peran individu di masyarakat dan sebagai anggota masyarakat. Akibat dari hubungan interaksi sehingga melahirkan bidang-bidang ilmu pengetahuan sosial, diantaranya seperti ekonomi, sosiologi, antropologi, ilmu politik, geografi dan sejarah.

Agama di dalam prespektif masyarakat, memiliki peran menentukan dan membentuk moralitas perilaku manusia yang lebih ramah terhadap lingkungan. Sebagai sumber perilaku yang dapat menuntun manusia, Agama islam memberikan konsep tentang hubungan individu dengan tuhannya yaitu Allah dan hubungan individu dengan individu lainnya. Hal inilah yang bisa menjadi acuan dalam konteks pendidikan sebagai pendekatan integratif pada pembelajaran IPS.

\footnotetext{
${ }^{1}$ R. Ahmadi, Pengantar Pendidikan Asas Dan Filsafat Pendidikan (Yogyakarta: Ar-Ruzz Media, 2014).
} 
Berbagai usaha dilakukan dalam perkembangan pendidikan, dengan tujuan dapat membentuk dan membina pengendalian diri pada siswa. Self control atau pengendalian diri merupakan kemampuan pengendalian diri dengan keadaan sadar sepenuhnya akan apa yang dilakukan, melakukan hal-hal yang baik dan menghindari hal-hal yang buruk. Kemampuan ini berasal dari kecerdasan emosi (Emosional Quotient/ EQ). Sebagai fungsi psikis, emosi sangat mempengaruhi proses belajar. Emosi tidak selalu berhubungan tentang hal negatif saja, namun bisa berbentuk positif. Hal tersebut tergantung bagaimana individu bisa mengendalikannya.

Kemampuan pengendalian diri, masing-masing individu memilki mekanisme yang dapat membantu mengendalikan perilakunya. Self control juga bisa diartikan sebagai salah satu potensi yang dapat dikembangkan dan digunakan pada proses menghadapi kondisi lingkungan sekitar. Individu dengan Self control yang baik biasanya memiliki kemampuan untuk menyusun, membimbing, mengatur, dan mengarahkan ke arah positif. Namun, jika yang terjadi sebaliknya, maka pendidikan hendaknya mampu membimbing siswa dalam mengendalian dirinya.

Persoalan yang masih terjadi pada proses pembelajaran adalah antara agama dengan pengetahuan sosial masih belum bersinergi. Sehingga upaya integrasi perlu dilakukan dengan tujuan mengembangkan pendidikan. Berbicara pengembangan pendidikan pada pembelajaran IPS, ada beberapa alternatif yang bisa digunakan. Misalnya, pendekatan tematik-integratif dengan mensinergikan tema-tema pembelajaran umum dan agama. Selain itu, bisa dengan pendekatan kontekstual, yaitudengan menghadirkan situasi pada dunia yang kemudian dikaitkan dengan nilai-nilai agama.

\section{Metode}

Penulis menggunakan metode penelitian deskriptif dan interprestasi. Pada metode ini, penulis mendeskripsikan tentang nilai agama dan pembelajaran IPS dalam membina Self control siswa. Tidak hanya itu saja, kemudian penulis menginterpretasikan nilai agama dan IPS sebagai Self control dalam pola integratif. Data yang diperoleh berasal dari buku, jurnal dan penelitian-penelitian sebelumnya untuk dijadikan sebagai acuan. 


\section{Pembahasan}

\section{Nilai-Nilai Agama Islam Sebagai Konsep Pembelajaran Self control}

Pembahasan mengenai nilai-nilai agama yang berfungsi sebagai Self control bukanlah sesuatu hal yang perlu diragukan lagi. Definisi nilai memiliki arti tentang susuatu yang diyakini kebenarannya dan dianut serta dijadikan sebagai acuan individu, masyarakat dalam menentukan sesuatu yang dianggap baik dan benar. Dalam pembentukan kompetensi siswa, nilai merupakan konsep pembelajaran. Oleh karena itu, nilai bisa memberikan warna dalam dunia pendidikan.

Sebagai agama yang dianggap benar bagi yang mempercayainya, konsep nilai pada agama islam menurut Sirait ${ }^{2}$, dibagi menjadi dua konsep yaitu nilai spiritual dan nilai sosial, serta keduanya memiliki peranan yang sama besar. Kemudian didalam keduanya memiliki dapat dibedakan menjadi tiga aspek, yaitu: (1) aqidah, (2)ibadah, dan (3) akhlaq. Menurut Hakim, nilai-nilai yang diajarkan dalam agama islam merupakan nilai-nilai yang mampu membawa manusia pada kebahagiaan, kesejahteraan, keselamatan, baik di kehidupan dunia maupun kehidupan setelahnya.

Pada penelitian Ragwan Mohsen Alaydrus, yang berjudul Membangun Kontrol Diri Remaja Melalui Pendekatan Islam Neuroscience, menggambarkan bagaimana perubahan fisik, emosional, dan kognitif pada usia remaja. Penelitian tersebut menyimpulkan bahwa proses meuju dewasa oleh seorang remaja harus dibentengi dengan fondasi spiritual dan psikologis supaya individu memperoleh kemampuan pengendalian diri.

Pada intinya, nilai dan agama merupakan komponen dalam pembentukan moral individu. Pada perkembangan pendidikan, agama mulai masuk ke dalam ranah pembelajaran. Sebab agama memiliki nilai untuk dijadikan sebagai acuan pembelajaran sehingga bisa menjadi fondasi spiritual bagi siswa yang nantinya membina pengendalian diri.

\section{Prespektif IPS Menjadi Bagian Pembelajaran Pengendalian Diri}

Proses pembelajar menjadi salah satu bagian dalam pendidikan. Kegiatankegiatan pembelajaran harus disusun sedemikian rupa supaya mendukung dan mengembangkan pengetahuan bagi peserta didik dalam membentuk watak dan karakter. Kurikulum juga menjadi bagain dari peroses pembelajaran yang berguna sebagai acuan dan inovasi pendidikan. Menurut Supriatna (2012) dalam Ridwan

\footnotetext{
${ }^{2}$ A. M. Sirait and A. P. Sirait, Iman Di Tengah Dinamika Budaya (Ekpresi, Misi, Dan Fungsi Agama Di Tengah Pluralitas (Yogyakarta: Program Studi Menejemen Pendidikan Islam UIN Sunan Kalijaga, 2017).
} 
(2014) kurikulum haruslah merupakan sebuha konsep yang tidak terdapat kepentingan-kepentingan dari penguasa, serta terdapat relevansi antara kondisi sosial dengan kebutuhan. ${ }^{3}$

Konsep kurikulum baru diperkenalkan untuk menyongsong pendidikan pada abad 21 oleh Komisi Nasional IPS di Amerika, dikutip oleh Wahyu. Konsep kurikulum ini harus dikembangkan secara sempurna dan baik dalam mencakup pemahaman yang jelas terhadap peranan-peranan secara konsisten. IPS mampu dan dapat berintegrasi dengan bidang ilmu lainnya, sebab hubungan IPS ditunjukkan secara jelas antara humaniora dan ilmu-ilmu pengetahuan alam dan fisik. Selain itu, pengetahuan IPS tidak hanya untuk dihafal dan diterima begitu saja, melainkan menjadi nilai kehidupan yang bisa berguna untuk peristiwa-peristiwa di masa yang akan datang. ${ }^{4}$

Salah satu bidang ilmu pendidikan, kajian dalam IPS berhubungan tentang pengembangan sosial. Menurut Soemantriyang dikutip Ridwan di dalam jurnalnya, Pendidikan IPS merupakan sutu penyederhanaan disiplin ilmu-ilmu sosial, dan disiplin ilmu lain serta masalah-masalah sosial terkait. ${ }^{5}$

Hal yang sama juga dijelaskan dalam Permendiknas No 22 tahun 2006, bahwa standart mata pelajaran IPS memberikan manfaat pada peserta didik supaya memiliki kemampuan sebagai berikut: (1) mengenal konsep tengan masyarakat dan lingkungan, (2) memiliki kemampuan dasar untuk berfikir kritis, logis, kaingin tahuan, dan memecahkan masalah, (3) berkomitmen dengan nilai-nilai sosial dan kemanusiaan, (4) memiliki kemampuan dasar untuk dapat berbungan dalam masyarakat yang majemuk.

\section{Pola dan Pendekatan Integrasi dalam Pendidikan}

Pembahasan ilmu agama dan ilmu pengetahuan masih menjadi isu hangat di berbagai kalangan, terutama akademisi. Paradigma yang melatar belakangi isu ini adalah karena adanya pandangan bahwa masing-masing bidang ilmu tersebut memiliki pembahasan yang berbeda. Menurut Rosyidi 2009 yang dikutip oleh Hidayatullah, agama oleh sebagian orang dipahami sebagai cita rasa dari konteks rohani, sedangkan perkembangan ilmu pengetahuan mampu menunjukkan keberhasilan yang dirasakan nyata. ${ }^{6}$

\footnotetext{
${ }^{3}$ A. E. Ridwan, "Pendidikan IPS Dalam Membentuk SDM Beradab," JPIS Jurnal Pendidikan Ilmu Sosial 23, no. 1 (2013): 27-36.

${ }^{4}$ Wahyu, Mewacanakan Pendidikan IPS (Bandung: FKIP-Unlam Press, 2013).

${ }^{5}$ Ridwan, "Pendidikan IPS Dalam Membentuk SDM Beradab."

${ }^{6}$ Hidayatullah, Relasi Ilmu Pengetahuan Dan Agama (ICECRS, 2016).
} 
Mengembangkan pengetahuan tidak hanya membahas tentang kedudukan manusia yang memiliki kendali penuh. Pengembangan ilmu pengetahuan seharusnya menjadi tolak ukur individu tentang sumber dari hakikat kebenaran. Dalam ajaran Islam, semua kebenaran berasal dari tuhan. oleh karena itu, integrasi antara ilmu pengetahuan dan ilmu agama tidak perlu diragukan dalam bidang pengembangan pendidikan. ${ }^{7}$

Berbicara pengembangan pendidikan pada pembelajaran IPS, ada beberapa alternatif yang bisa digunakan. Misalnya, pendekatan tematik-integratif dengan mensinergikan tema-tema pembelajaran umum dan agama. Selain itu, bisa dengan pendekatan kontekstual, yaitu dengan menghadirkan situasi pada dunia nyata yang kemudian dikaitkan dengan nilai-nilai agama.

Konsep integrasi keilmuan sesungguhnya bukanlah hal baru dalam dunia pendidikan. Secara epistimologis, integrasi merupakan kata serapan dari integrate, integration yang kemudian diadaptasi ke dalam bahasa indonesia. Arti integrasi sendiri dalam kamus webster dictionary, merupakan suatu gabungan, perpaduan, kombinasi, harmoni, kebulatan, atau keseluruhan. Dengan kata lain, dapat diartikan suatu konsepsi yang madukan unsur-unsur yang berbeda menjadi satu kesatuan saling mengikat satu sama lain. ${ }^{8}$

Pada penelitian sebelumnya, oleh Sanusi dalam jurnal penelitiannya, menyebutkan bahwa:

"Integrasi sebagai sebuah pendekatan agama dalam pengembangan materi ajar IPS, hadir sebagai upaya untuk memberikan sebuah tawaran alternatif atas persoalan akibat fanatisme-fanatisme tertentu yang berujuang pada titik kebuntuan kontra produktif. Pada konteks ini, integrasi adalah sebgai sebuah pendekatan untuk merekontruksi atas pemahaman-pemahaman sebelumnya yang selalu membatasi diri pada konsepsi-konsepsi tertentu."

Merujuk pada penelitian diatas, sinergitas antara Ilmu pengetahuan sosial dan ilmu keagamaan dapat menjadi kontruksi pemahaman-pemahaman sebelumnya. Dalam konteks ini, dengan memadukan konteks akal dan wahyu dimana konteks integrasi sebagai basis pendekatannya.

\footnotetext{
${ }^{7}$ H. Amiruddin and U. Husain, Integrasi Ilmu Dan Agama (Banda Aceh: Ar-Raniry Press Banda Aceh, 2007).

${ }^{8}$ Sanusi, "Integrasi Al-Qur'an, Sains Dan Ilmu Sosial Sebagai Model Pengembangan Materi Ajar IPS Di Madrasah,” Jurnal of Social Science Teaching IJTIMAIYA 1, no. 1 (2017).
} 


\section{Penutup}

Agama islam selain menjadi nilai spiritual juga menjadi nilai sosial, yang dalam konteks pendidikan terbukti mampu berperan sebagai fondasi spiritual. Tujuannya, agar siswa mampu memperoleh kemampuan pengendalian diri.

Pengendalian diri atau Self control meupakan upaya sadar dalam melakukan tindakan, antara individu dengan individu lainnya, atau individu dengan lingkungan sekitarnya. Individu mempunyai upaya masing-masing dalam pengendalian dirinya. Maka dari itu, setiap individu mempunyai kesempatan untuk dibekali pondasi agar dapat mengontrol tindakannya. Pendidikan menjadi salah satu media yang bisa memberikan edukasi dalam membina pengendalian diri.

IPS pada dasarnya merupakan mata pelajaran yang mengkaji tentang manusia sebagai mahluk sosial. Pembelajaran IPS kini mulai berkembang menjadi banyak bidang ilmu. Dari pengertian yang dipaparkan di atas, terdapat hubungan pendidikan IPS yang berkonsisten mengkaji ilmu sosial dan nilai-nilai sosial dengan tujuan memberikan pendekatan pengembangan karater dalam hal ini termasuk memiliki kemampuan Self control. Agama dan pembelajaran IPS memiliki kesamaan yaitu dapat menjadi acuan dalam pengembangan diri. Hasil yang diperoleh keduanya dapat menjadi pembelajaran dalam membina pengendalian diri.

\section{Daftar Pustaka}

Ahmadi, R. Pengantar Pendidikan Asas Dan Filsafat Pendidikan. Yogyakarta: ArRuzz Media, 2014.

Amiruddin, H., and U. Husain. Integrasi Ilmu Dan Agama. Banda Aceh: Ar-Raniry Press Banda Aceh, 2007.

Hidayatullah. Relasi Ilmu Pengetahuan Dan Agama. ICECRS, 2016.

Ridwan, A. E. "Pendidikan IPS Dalam Membentuk SDM Beradab." JPIS Jurnal Pendidikan Ilmu Sosial 23, no. 1 (2013): 27-36.

Sanusi. "Integrasi Al-Qur'an, Sains Dan Ilmu Sosial Sebagai Model Pengembangan Materi Ajar IPS Di Madrasah." Jurnal of Social Science Teaching IJTIMAIYA 1, no. 1 (2017).

Sirait, A. M., and A. P. Sirait. Iman Di Tengah Dinamika Budaya (Ekpresi, Misi, 
Dan Fungsi Agama Di Tengah Pluralitas. Yogyakarta: Program Studi Menejemen Pendidikan Islam UIN Sunan Kalijaga, 2017.

Wahyu. Mewacanakan Pendidikan IPS. Bandung: FKIP-Unlam Press, 2013.

Copyright (C) 2020Journal Dirasah: Vol. 3, No.2, Agustus 2020, p-ISSN: 2615-0212, e-ISSN; 2621 2838

Copyright rests with the authors 
98 Mukti Ali, Siti Rohmah, dan Nur Hidayati Andrajati

Copyright of Jurnal Dirasah is the property of Jurnal Dirasah and its content may not be copied oremailed to multiple sites or posted to a listserv without the copyright holder's express writtenpermission. However, users may print, download, or email articles for individual use.

https://ejournal.iaifa.ac.id/index.php/dirasah 